\title{
Quantitative Comparison of Algorithms for Estimating the Air-sea Exchange of Carbon Dioxide in Malacca Straits
}

\author{
Lilik Maslukah ${ }^{1 *}$, Didi Adisaputro² and Widodo Setiyo Pranowo ${ }^{3,4}$ \\ ${ }^{1}$ Department of Oceanography, Faculty of Fisheries and Marine Science, Diponegoro University \\ J. Prof. H. Soedarto, S.H, Tembalang, Semarang, Indonesia 50275 \\ Institut Teknologi Sumatera \\ Jl. Terusan Ryacudu, Sabah Balau, Tj. Bintang, South Lampung, Lampung, Indonesia 35365 \\ ${ }_{3}^{3}$ Marine Research Center, Agency for Marine \& Fisheries Research \& Human Resources, Ministry of Marine \\ Affairs \& Fisheries of the Republic of Indonesia \\ Komplek Bina Samudera JI. Pasir Putih II 2nd BRSDM KP Building $4^{\text {th }}$ floor, Jakarta Indonesia 14430 \\ 4The Department of Hydrography, Indonesian Naval Postgraduate School (STTAL) \\ J. Pantai Kuta V, Jakarta, Indonesia 14430 \\ Email: lilik_masluka@yahoo.com
}

\begin{abstract}

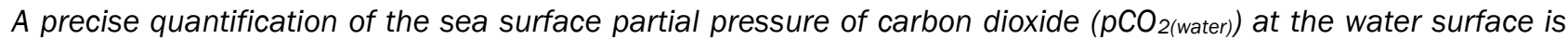
required in order to define the role of the sea in air-sea exchange of $\mathrm{CO}_{2}$. Even though the $\mathrm{pCO}_{2 \text { (water) }}$ can be measured directly, the semi-empirical model has seen numerous application in determining the $\mathrm{pCO}_{2}$ (water) due to a time-and cost-efficient. This study aims to compare the $\mathrm{pCO}_{2}$ and $\mathrm{FCO}_{2}$ (Flux of $\mathrm{CO}_{2}$ ) calculated using Zhai and Zhu algorithm with the underway datasets of $\mathrm{pCO}_{2}$ obtained during the scientific cruise of CISKA-SPICE III in April 2013. The partial pressure of $\mathrm{CO}_{2}\left(\mathrm{pCO}_{2}\right)$ was measured using a high-accuracy electrochemical instrumentation underway HydroC/CO $/ \mathrm{CO}_{2} \mathrm{FT}$ (flow through) with an error $\pm 1 \mu \mathrm{atm}$. Furthermore, in order to calculate the $\mathrm{pCO}_{2}$ and the $\mathrm{FCO}_{2}$ employing widely used algorithms, some data were needed including wind speed, sea surface temperature and chlorophyll-a extracted from MODIS (Moderate Resolution Imaging Spectroradiometer). According to the results obtained, the difference between the $\mathrm{pCO}_{2}$ and $\mathrm{FCO}_{2}$ derived from those two algorithms are significant. The underway datasets of $\mathrm{pCO}_{2}$ are ranging from 409.52-544.01 $\mu$ atm. Meanwhile, the $\mathrm{pCO}_{2}$ derived using the Zhai algorithm and Zhu algorithm are between 405.003-422.79 $\mu$ atm and 398.94-752.06

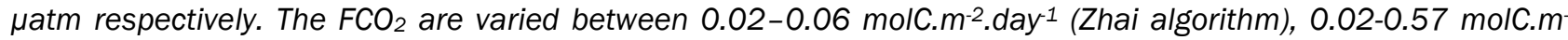
${ }^{2}$. day $^{-1}$ (Zhu algorithm) dan 0.04-0.23 molC. $\mathrm{m}^{-2}$.day ${ }^{-1}$ (the underway datasets). A comparison of the two results reveals that $\mathrm{pCO}_{2}$ derived using Zhai algorithm is closer with the underway datasets compared with the result of $\mathrm{pCO}_{2}$ calculated using Zhu algorithm with the MRE (Mean Relative Estimation Error) as large as 19.4\% and 39\% respectively. Taken together, these results suggest that the Zhai algorithm is more appropriate to determine algorithms for estimating the air-sea exchange of carbon dioxide in the Malacca Straits
\end{abstract}

Keywords: carbon dioxide, Malacca Straits, $\mathrm{pCO}_{2}, \mathrm{FCO}_{2}$, Zhai and Zhu algorithm

\section{Introduction}

The rate of $\mathrm{CO}_{2}$ emission because of anthropogenic mainly originated from land-use change and fossil fuel combustion has increased by

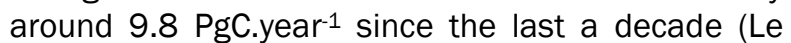
Quéré et al., 2015). Indonesia that has a vast area of tropical forest and widely known for its potential $\mathrm{CO}_{2}$ uptake. However, the role of the forest in absorbing carbon dioxide has decreased due to the conversion of the forest to be a residence area. Indonesia also has a vast area of ocean, which is $3,288,680 \mathrm{~km}^{2}$ or around $63 \%$ of its total area of Indonesia. Ocean has also known having the ability to absorb $\mathrm{CO}_{2}$ (carbon sink) or to desorb $\mathrm{CO}_{2}$ (carbon source). It is fundamental to diagnose the dynamics of the $\mathrm{CO}_{2}$ transport by an oceanic carbon reservoir in order to make an accurate projection of global warming (lida et al., 2015).

The Air-sea exchange of carbon dioxide can be examined by calculating the difference between the partial pressure of $\mathrm{CO}_{2}$ in the atmosphere and the sea $\left(\triangle P \mathrm{PO}_{2}\right)$. This $\triangle P C \mathrm{O}_{2}$ gives a thermodynamic driving force in order to reach equilibrium state of the $\mathrm{CO}_{2}$ concentration. It can be calculated by using methods such as direct measurement ( $\mathrm{Yu}$ et al., 2013), the approach of carbonate system (Adi and Rustam, 2010; Wahyono, 2011) and remote sensing data including temperature and chlorophyll-a (Zhai, 
2005; Susandi et al., 2006; Ramawijaya et al., 2012).

Employing the algorithms in which data mainly derived from satellite remote sensing has been widely applied on research related to $\mathrm{CO}_{2}$ fluxes (Song et al., 2016). The utilization of remote sensing can provide benefits because it produces information of sea surface temperature and chlorophyll-a, which cover a vast area and extended periods of time. The cost associated, with the data collection, is also much lower than direct measurement. However, Ramawijaya et al. (2012) research at Banten waters shows that the approach for defining the $\mathrm{CO}_{2}$ flux using Zhu algorithm (Zhu et al., 2009) still contains errors. This Zhu algorithm does not appropriate to be employed in the coastal waters or estuary.

Even though it has advantages of analyzing a large area over time, applying an algorithm for determining the $\mathrm{pCO}_{2}$ can be a challenge due to the complexity as a result of a combination various factors. Thus, finding the most appropriate algorithm to be applied in certain water is crucial (HernándezCarrasco et al., 2015; Song et al., 2016). Some studies (Wang et al., 2010; Hales et al., 2012; Turi et al., 2014; Hernández-Carrasco et al., 2016; Chen et al., 2016 Song et al., 2016) related to the identification of $\mathrm{pCO}_{2}$ and air-sea $\mathrm{CO}_{2}$ flux using both algorithms and underway datasets has also been conducted. However, none of them applies this research approach in Malacca strait.
This research aims to compare the $\mathrm{pCO}_{2}$ and $\mathrm{FCO}_{2}$ (Flux of $\mathrm{CO}_{2}$ ) calculated using Zhai and Zhu algorithm, including its comparison to the underway datasets of $\mathrm{pCO}_{2}$ obtained during the scientific cruise of CISKA-SPICE III on April 2013 (Wit et al., 2015). Thus, the most suitable algorithm which has lowest MRE relative to the underway datasets of $\mathrm{pCO}_{2}$ can be used in the future works for examining $\mathrm{CO}_{2}$ flux in tropical waters mainly in the Malacca strait.

\section{Material and Methods}

The materials that are used in this research are aqua-Modis satellite remote sensing, underway datasets of $\mathrm{pCO}_{2}$, and direct measurement of atmospheric $\mathrm{pCO}_{2}$. The Sea Surface Temperature (SST), wind speed and Chlorophyll-a are extracted from the satellite imagery using Arc-GIS 10.1. Direct measurement was conducted during the scientific cruise of CISKA-SPICE III Cruise on 02-17 April 2013 (Mayer et al., 2013). CISKA-SPICE III, is a joint research program between Research and Development Center for Marine and Coastal Resources (P3SDLP-Indonesia) and The Leibniz Center for Tropical Marine Ecology (ZMT-Bremen). SPICE (Science for the Protection of Indonesian Coastal Marine Ecosystems), which has a grand topic of "Climate change \& the ocean: carbon sequestration in Indonesian Seas \& their global significance: generation of scientific Knowledge for formulating strategies for adaptation to climate change" (CISKA). Moreover, the location of sampling station is provided in Figure 1.

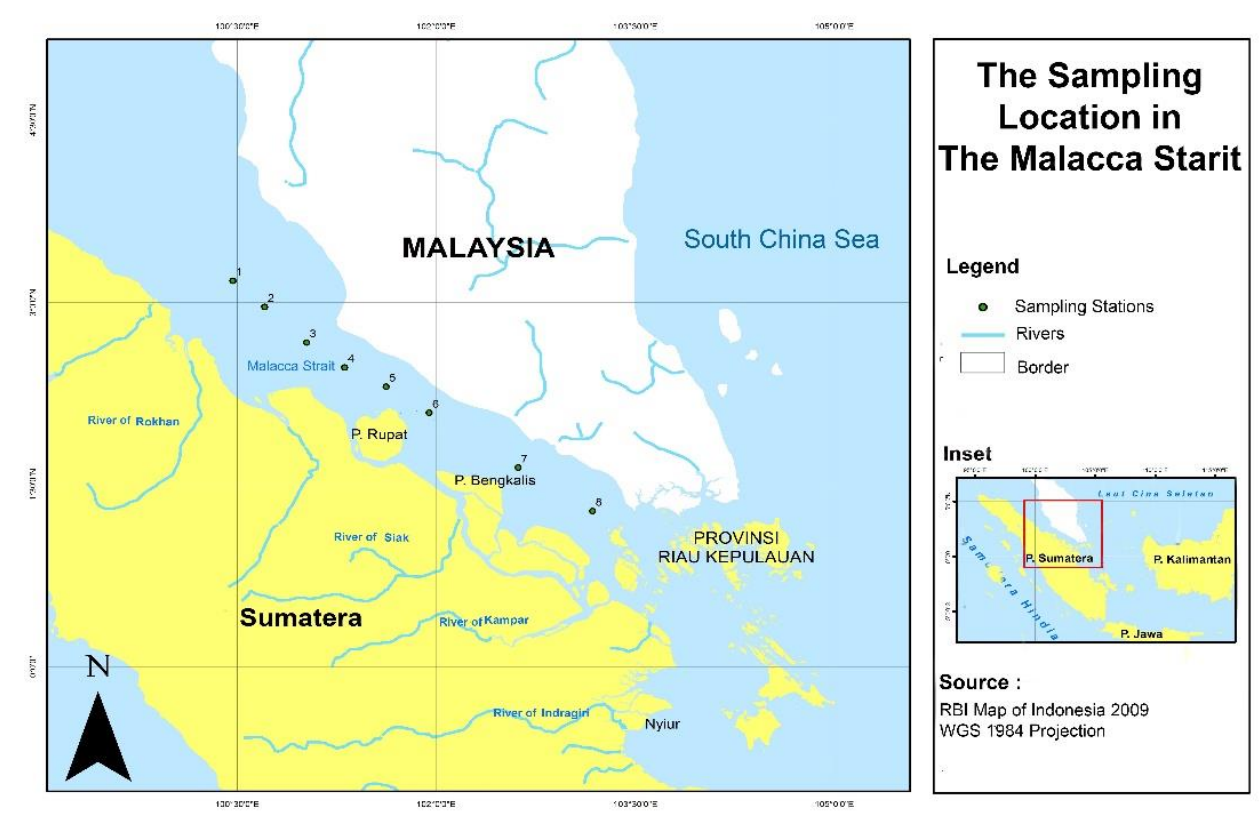

Figure 1. The Location of Sampling Station 


\section{Methods for $\mathrm{pCO}_{2}$ calculation}

In addition to the $\mathrm{pCO}_{2}$ underway datasets, the $\mathrm{pCO}_{2}$ data was also obtained, $p \mathrm{CO}_{2}$ is computed using an algorithm that is developed by Zhu et al. (2009), $\mathrm{pCO}_{2}$ computation using methods that have been employed by Zhai et al. (2005) and the $\mathrm{pCO}_{2}$ determination through field measurement using HydroC FT flow ( $\pm 1 \mu \mathrm{atm})$.

\section{Carbon dioxide flux calculation}

Flux, in here, is known as the transport of $\mathrm{CO}_{2}$ between the atmosphere and the ocean. It is a function consisting of two variables including the $\mathrm{CO}_{2}$ concentration gradient between atmosphere and ocean, which is representing of thermodynamic function; and the gas transfer velocity of $\mathrm{CO}_{2}$ as a function of sea surface hydrodynamics. The equation used is provided as follow.

$$
\mathrm{F}=\mathrm{KK}_{0}\left(p C \mathrm{O}_{2(A q)}-p C \mathrm{O}_{2(\text { air })}\right)
$$

Where:

$$
\begin{aligned}
& \mathrm{F} \quad \text { : Flux of } \mathrm{CO}_{2}\left(\mathrm{~mol} . \mathrm{m}^{-2} \cdot \mathrm{d}^{-1}\right) \\
& \mathrm{k} \quad \text { : Velocity of gas transfer }\left(\mathrm{cm} \cdot \mathrm{hr} \mathrm{-}^{-1}\right) \\
& \mathrm{Ko}: \text { Coefficient of } \mathrm{CO}_{2} \text { gas solubility }\left(\mathrm{mol}^{-\mathrm{L}^{-1}} \cdot \mathrm{y}^{-1}\right) \\
& \mathrm{pCO}_{2} \text { : Partial pressure of } \mathrm{CO}_{2}
\end{aligned}
$$

\section{$\mathrm{CO}_{2}$ sink and source}

The equation below, was used to define whether a particular seawater acts as sink or source of $\mathrm{CO}_{2}$.

$$
\Delta p \mathrm{CO}_{2(\mathrm{Aq})}=\Delta p \mathrm{CO}_{2(\mathrm{Aq})}-p C \mathrm{O}_{2(\text { (air) }}
$$

In which the $\mathrm{pCO}_{2 \mathrm{~atm}}$ measured directly in the

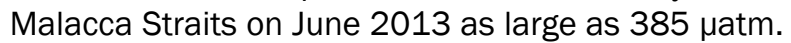
The ocean will be identified as a source of $\mathrm{CO}_{2}$ to the atmosphere if the $\triangle \mathrm{pCO}_{2}$ has a positive value. Meanwhile, it is defined as a sink if the $\triangle \mathrm{pCO}_{2}$ has a negative value (Zhai et al., 2005).

\section{Result and Discussion}

\section{Partial pressure of $\mathrm{CO}_{2}\left(\mathrm{pCO}_{2}\right)$}

The $\mathrm{pCO}_{2}$ computation using those three methods shows different results. The $\mathrm{pCO}_{2}$ values

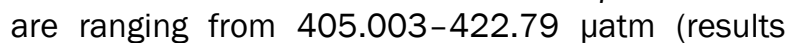
using the method of Zhai et al. (2005) and around

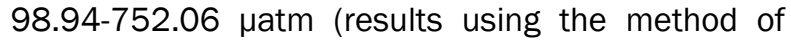
Zhu et al., 2009). Meanwhile, the result of $\mathrm{pCO}_{2}$ obtained from direct measurement is around

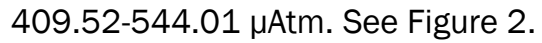

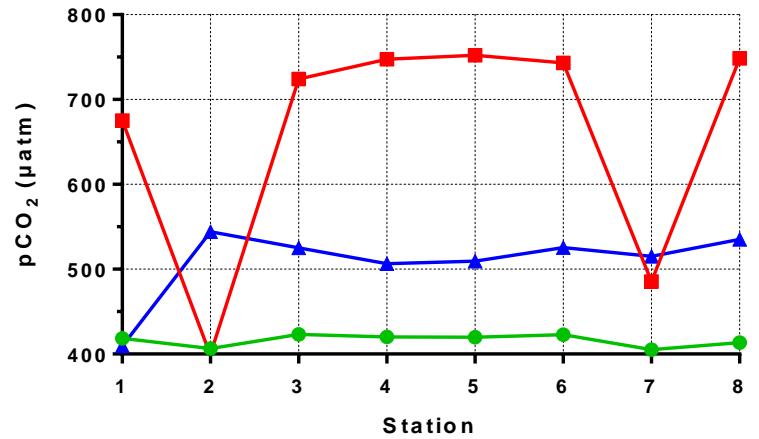

Figure 2. The $\mathrm{pCO}_{2}$ computation results of All Stations in Malacca Straits using Zhu and Zhai Methods, and its comparison with the field measurement Note : ${ }^{-}-{ }^{-}=$Zhau; $-{ }^{-}=$Zhu; ${ }^{-}-$Field Meassurement

The figure two demonstrates that the $\mathrm{pCO}_{2}$ computed using the method of Zhu algorithm at station $1,3,4,5,6$, and 8 have the highest $p \mathrm{CO}_{2}$ compared with another method at the same observation station. Station 2 and 7 computed using the method of Zhu algorithm are identified as the lowest $\mathrm{pCO}_{2}$ due to the low concentration of chlorophyll-a. In this approach, chlorophyll-a is powered by two which is considerably significant when it comes to the result. The concentration of chlorophyll-a in the station 2 and 7 are extremely low only around 1-2 mg. $\mathrm{m}^{-3}$. Unlike Zhu algorithm, the Zhai algorithm relies not only on a single parameter. A parameter of SST and Chl-a is take into account in order to obtain more accurate $\mathrm{pCO}_{2}$ prediction. According to Zhai et al. (2005), the involvement of diurnal variations of phytoplankton metabolism will affected $\mathrm{pCO}_{2}$ nonlinearly.

In order to identify the suitability of the methods relative to the field measurement, a comparison of the Mean Relative Error (MRE), between indirect measurement and the value from direct measurement, is one of the best approaches. The computation results shows that the MRE based on Zhai algorithm is around $19.40 \%$, while based on Zhu algorithm is about $38.96 \%$. Thus, it can be said that the result obtained using the Zhai algorithm is closer to the real data from direct measurement. Even though, the Zhu Algorithm employing more complex equation, involving the derivation of $\mathrm{Chl}-\mathrm{a}$ and SST rather than a single parameter. It is almost certain that this method only suitable for the $\mathrm{pCO}_{2}$ estimation in the South China Sea that has been conducted by Zhu et al. (2009). According to their finding, the algorithm produces smaller MRE relative to the field datasets. It is suggested that this algorithm, for Malacca Strait application, should be 
further modified in order to obtain a more accurate pCO2 prediction. The Zhu algorithm can be used to obtain a closer result, with the field underway datasets, by reducing its constant from $5,715.94$ to 5,500 .

\section{Carbon dioxide flux}

$\mathrm{CO}_{2}$ flux varies from one method to another, and from one station to another. See Figure 3 . The computation results using Zhu algorithm shows the value is relatively higher compared with the other methods. The flux is highly positive correlated with the $\triangle \mathrm{pCO}_{2}$ between atmosphere and the ocean. Since the atmospheric pressure of $\mathrm{CO}_{2}$ is assumed to be remain stable, the pattern of $\mathrm{CO}_{2}$ fluxes and their MRE are almost similar, with the $\mathrm{pCO}_{2}$ analysis in Figure 3.

The results of the $\mathrm{CO}_{2}$ flux $\left(\mathrm{FCO}_{2}\right)$ calculation are varied from $0.02-0.06 \mathrm{~mol}^{-2} \mathrm{~m}^{-1} \mathrm{~d}^{-1}$ (using Zhai algorithm), 0.02-0.57 mol.m- $\mathrm{m}^{-2} \cdot \mathrm{d}^{-1}$ (using Zhu algorithm), and 0.04-0.23 mol. $\mathrm{m}^{-2} \cdot \mathrm{d}^{-1}$ (based on direct measurement). According to Susandi et al. (2008), using the method of Zhai et al. (2005) in the northern part of Indonesian waters reveals a $\mathrm{CO}_{2}$ flux as large flux as $2.6 \mathrm{~mol} \mathrm{~m}^{-2} \cdot \mathrm{y}^{-1}\left(0.07 \mathrm{~mol} \cdot \mathrm{m}^{-2} \cdot \mathrm{d}^{-1}\right)$. There is no $\mathrm{FCO}_{2}$ prediction that has been computed in the Malacca strait. However, generally speaking, this value is still much lower compared with the value computed in Florida Bay, using a method of $\mathrm{CO}_{2}$ system approach. It is ranging of 59.9-40.3 $\mathrm{mmol} \mathrm{m}{ }^{-2} \cdot \mathrm{d}^{-1}$, with the average of $29.6 \mathrm{mmol} \mathrm{m} \mathrm{m}^{-2} \cdot \mathrm{d}^{-1}$ (Dufore, 2012). According to Ekayanti and As-syakur (2011), the average of $\mathrm{CO}_{2}$ flux in Indonesian waters is around $3.8 \mathrm{~mol} \mathrm{~m}^{-2} \cdot \mathrm{y}^{-1}$. It is completely very lower than in the South China Sea. In the South China Sea, the maximum $\mathrm{CO}_{2}$ flux is $36.14\left(\mathrm{~mol} \mathrm{~m}^{-2} \cdot \mathrm{y}^{-1}\right)$, with the SST values of $22.51^{\circ} \mathrm{C}$ to $29.32^{\circ} \mathrm{C}$ (Zhai et al., 2013). Meanwhile, The Zhai et al. (2013) explained that the South China Sea acts as a $\mathrm{CO}_{2}$ source to the atmosphere only during the fall season, which the flux is around 0.4-0.5 mmol. $\mathrm{m}^{-2} \cdot \mathrm{d}^{-1}$.

The Malacca strait has a unique characteristic due to its physical and chemical properties of seawater, which influences by the water supply from some big rivers in Indonesia and Malaysia. The study that was carried out by Wit et al. (2015), suggests that $\mathrm{CO}_{2}$ fluxes from those rivers amount to $66.9 \pm 15.7$ TgC per year, of which Indonesia and Malaysian rivers releases $53.9 \pm 12.4 \operatorname{TgC}$ per year and $6.2 \pm 1.6 \mathrm{TgC}$ per year respectively. Furthermore, Wit et al. (2015) said that the $\mathrm{CO}_{2}$, which is potentially caused by the primary source of DOC near the coast, is transported by the river. The DOC is most likely transported to the Malacca strait and contributes to the outgassing of $\mathrm{CO}_{2}$ in the Malacca Strait (Wit et al., 2015).

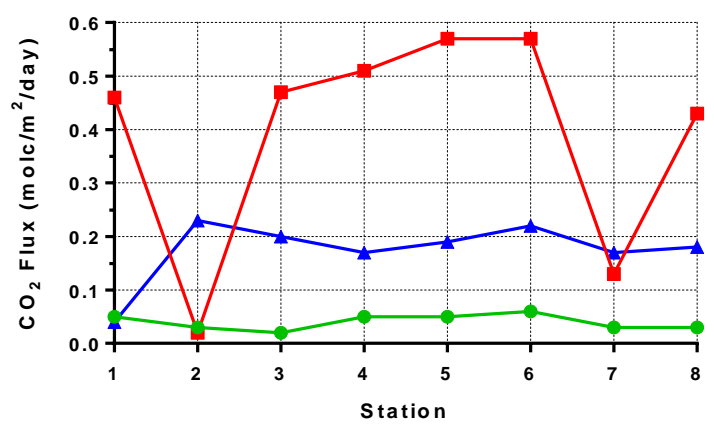

Figure 3. The $\mathrm{FCO}_{2}$ computation results of All Stations in Malacca Straits using Zhu and Zhai Methods, and its comparison with the field measurement Note : ${ }^{-}-$Zhau $^{-}{ }^{-}=\mathrm{Zhu}^{-}{ }^{-}-$= Field Meassurement

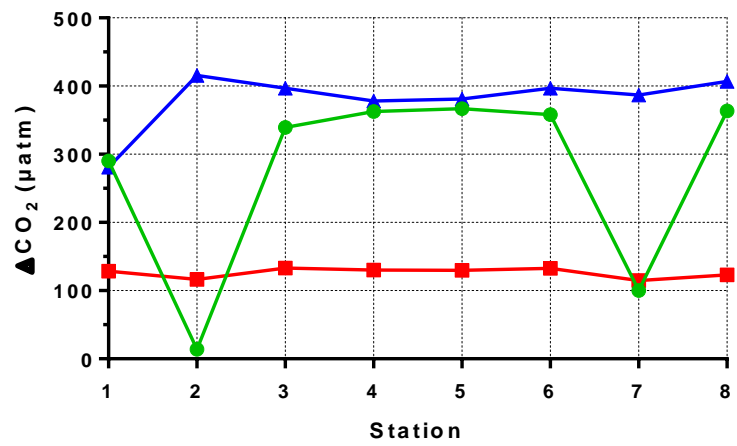

Figure 4. The $(\Delta) \mathrm{pCO}_{2}$ between ocean and atmosphere in all stations of Malacca Straits based on Zhu and Zhai Algorithms, including its filed measurement. Note : ${ }^{-}=$Zhau; ${ }^{-}=$Zhu; $-1-=$ Field Meassurement

In order to identify whether the waters is considered as a source or a sink of $\mathrm{CO}_{2}$, can be done by defining the differences between $\mathrm{pCO}_{2}$ value in the seawaters and $\mathrm{pCO}_{2}$ value in the atmosphere. The computation result shows that, the seawater acts as a $\mathrm{CO}_{2}$ sources. The differences of $\mathrm{pCO}_{2}$ $\left(\Delta \mathrm{pCO}_{2}\right)$ values can be seen in Figure 4.

\section{Conclusion}

The $\mathrm{pCO}_{2}$ computation results based on Zhai algorithm and Zhu algorithm are ranging from

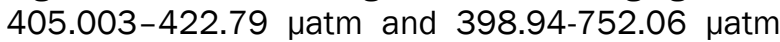
respectively. Meanwhile, the $\mathrm{pCO}_{2}$ from the field observation is ranging from 409.52-544.01 $\mu \mathrm{atm}$. It is the evidence that the Malacca Straits act as a $\mathrm{CO}_{2}$ sources to the atmosphere. The computation result of the partial pressure of $\mathrm{CO}_{2}\left(\mathrm{pCO}_{2}\right)$ in the ocean by 
using the Zhai algorithm is closer (MRE 19.4\%), to the $\mathrm{pCO}_{2}$ value of field measurement, than its computed based on Zhu algorithm (MRE 39\%).

\section{Acknowledgments}

This work was carried out as part of Science for Protection Indonesian Coastal Marine Ecosystems (SPICE) III, a joint research program between Research and Development Center for Marine and Coastal Resources (P3SDLP-Indonesia) and The Leibniz Center for Tropical Marine Ecology (ZMT-Bremen). CISKA-SPICE III Cruise is collaboratively funded by all institutions in SPICE III Topic 2 Program (Coordinators: Dr. Widodo Pranowo \& Dr. Tim Rixen). We would like to gratefully acknowledge everyone that involved in the CISKA Cruise survey and whole the SPICE III Program. The authors would also like to thank the Marine \& Coastal Data Laboratory (MCDL) at KKP, and Afdal Djalus from P2O-LIPI, for all facilitation during the atmospheric $\mathrm{pCO}_{2}$ data computation for this work.

\section{References}

Adi, N.S. \& Rustam, A. 2010. Studi Awal Pengukuran Sistem $\mathrm{CO}_{2}$ Di Teluk Banten. Prosiding Pertemuan IImiah Tahunan VI. Ikatan Sarjana Oseanologi Indonesia. Jakarta.

Chen, S., Hu, C., Byrne, R.H., Robbins, L.L. \& Yang, B. 2016. Remote estimation of surface pCO2 on the West Florida Shelf. Continental Shelf Res. 128:10-25. doi: 10.1016/j.csr.20 16.09.004

Dufore, C.M. 2012. Spatial and Temporal Variations in the Air-Sea Carbon Dioxide Fluxes of Florida Bay. Graduate Theses and Dissertations. University of South Florida. 69p.

Ekayanti, N.W. \& As-Syakur, A.R. 2011. C02 Flux in Indonesian Water Determined by Satellite Data. Int. J. Remote Sensing Earth Sci. 8:1-12

Hales, B., Strutton, P.G., Saraceno, M., Letelier, R., Takahashi, T., Feely, R., \& Chavez, F. 2012. Satellite-based prediction of pCO2 in coastal waters of the eastern North Pacific. Prog. Oceanog. 103:1-15. doi: 10.1016/j.pocean. 2012.03.001

Hernández-Carrasco, I., Sudre, J., Garçon, V., Yahia, H., Garbe, C., Paulmier, A., Dewitte, B., Illig, S., Dadou, I., González-Dávila, M. \& SantanaCasiano, J.M., 2015. Reconstruction of super- resolution ocean pCO 2 and air-sea fluxes of CO 2 from satellite imagery in the southeastern Atlantic. Biogeosciences, 12(17): 5229-5245. doi: 10.5194/bg-12-5229-2015

lida, Y., Kojima, A., Takatani, Y., Nakano, T., Sugimoto, H., Midorikawa, T. \& Ishii, M. 2015. Trends in pCO2 and sea-air $\mathrm{CO} 2$ flux over the global open oceans for the last two decades. J. Oceanog. 71(6):637-661. doi: 10.1007/s108 72-015-0306-4

Le Quéré, C., Moriarty, R., Andrew, R.M., Peters, G.P., Ciais, P., Friedlingstein, P., Jones, S.D., Sitch, S., Tans, P., Arneth, A. \& Boden, T.A. 2015. Global carbon budget 2014. Earth System Sci. Data, 7(1):47-85. doi: 10.5194/essd-7-47-2015

Mayer, B., Samiaji, J. \& Elizal, H. 2013. Report of Research Cruise MTK-2013. Indonesia-German Science for the Protection of Indonesian Coastal marine Ecosystems. 12 pp.

Ramawijaya, M.Y., Awaludin, Pranowo, W.S. \& Rosidah. 2012. Pemanfaatan Algoritma Zhu untuk Analisis Karbon Laut di Teluk Banten. J. Horpodon Borneo. 5(2):131-136.

Song, X., Bai, Y., Cai, W-J., Chen, C-T., Pan, D., He, X. \& Zhu, Q. 2016. Remote Sensing of Sea Surface pCO2 in the Bering Sea in Summer Based on a Mechanistic Semi-Analytical Algorithm (MeSAA). Remote Sensing. 8(7): 558. doi: $10.3390 /$ rs8070558

Turi, G., Lachkar, Z. \& Gruber, N. 2014. Spatiotemporal variability and drivers of pCO 2 and air-sea CO 2 fluxes in the California Current System: an eddy-resolving modeling study. Biogeosciences, 11(3):671-690. doi: 10.5194 /bg-11-671-2014

Wahyono, I.B. 2011. Kajian Biogeokimia Perairan Selat Sunda dan Barat Sumatera ditinjau dari Pertukaran Gas Karbondioksida $\left(\mathrm{CO}_{2}\right)$ antara laut dan udara. Thesis. FMIPA. Universitas Indonesia (UI). Jakarta.

Wang, X.J. 2010. Spatial and temporal variations in the sea surface pCO2 and air-sea CO2 flux in the equatorial Pacific: model sensitivity to gas exchange and biological formulations. Biogeosciences Discussions. 7(3):3879-3910. doi: 10.5194/ bgd-7-3879-2010

Wit, F., Müller, D., Baum, A., Warneke, T., Pranowo, W.S., Müller, M. \& Rixen, T. 2015. The impact of disturbed peatlands on river outgassing in 
Southeast Asia. Nature Communications, 6:10155. doi: $10.1038 / \mathrm{n}$ comms 10155

Yu, P., Zhang, H., Zheng, M., Pan, J. \& Bai, Y. 2013. The partial pressure of carbon dioxide and airsea fluxes in the Changjiang River Estuary and adjacent Hangzhou Bay. Acta Oceanologica Sinica, 32(6):13-17. doi: 10.1007/s13131-01 3-0320-6

Zhai, W., Dai, M., Cai, W.J., Wang, Y. \& Hong, H. 2005. The partial pressure of carbon dioxide and air-sea fluxes in the northern South China Sea in spring, summer and autumn. Mar. Chem. 96(1):87-97. doi: 10.1016/j.marchem. 2004.12.002
Zhai, W.D., Dai, M.H., Chen, B.S., Guo, X.H., Li, Q., Shang, S.L., Zhang, C.Y., Zhai, W.D., Chen, B.S., Cai, W.J. \& Cai, W.J. 2013. Seasonal variations of sea-air $\mathrm{CO} 2$ fluxes in the largest tropical marginal sea (South China Sea) based on multiple-year underway measurements. Biogeosciences. 10:7775-7791. doi: 10.51 94/bg-10-7775-2013

Zhu, Y., Shang, S., Zhai, W. \& Dai, M. 2009. Satellitederived surface water $\mathrm{pCO}_{2}$ and air-sea $\mathrm{CO}_{2}$ fluxes in the northern South China Sea in summer. Prog. Natural Sci. 19(6):775-779. doi: 10.1016/j.pnsc.2008.09.004 